\title{
高齢者施設の室内環境及び空調設備の管理実態に関する全国調査 MANAGEMENT SITUATION OF INDOOR ENVIRONMENT
AND HVAC SYSTEM IN FACILITIES FOR THE ELDERLY
}

\author{
金勲*, 阪東 美智子**, 大澤 元 毅*, 林 基 哉*** \\ Hoon KIM, Michiko BANDO, Haruki OSAWA \\ and Motoya HAYASHI
}

\begin{abstract}
Japan has been well on the way to an aging society and entered a super-aged society at 21.5 percent aging rate in 2007, and the facility demand for the elderly is increasing rapidly. However, the actual situation of indoor environment had not been clear because there is not a regulation and control law at all. It is critical to understand the facility managing system and the actual condition of indoor environment in order to improve quality of life such as health and comfort and to prevent infectious diseases in care welfare facilities for the elderly. Cross-sectional study utilizing the questionnaire survey on special nursing homes all over the country was conducted to clarify the management, maintenance and actual condition of indoor environment and building equipment in 2013.

As a result, the installation of individual air conditioning equipment expanded countrywide due to benefits such as initial / operating costs and high energy performance. the control criteria of air temperature were set in about 60 percent of the facilities, while those for relative humidity and ventilation were less. Most of the facilities set control criteria for indoor environment factors within commonly-accepted levels, but a problem also was seen in knowledge and recognition of facility managers for HVAC and ventilation system. In order to secure and maintain the favorable indoor environment and hygiene in the elderly facilities, it seems appropriate to remark that a professional administrator should be employed as a facility manager, and they should be educated and provided with the related knowledge and techniques.
\end{abstract}

Keywords : Facility for the elderly, Special nursing home, Indoor environment, HVAC, Ventilation, Nationwide survey 高齢者施設，特別養護老人ホーム，室内環境，空調設備，換気，全国調査

\section{1. はじめに}

日本は 2007 年に超高齢社会に進入し、世界で最も高齢化が進んで いる中、それに伴う高齢者のための施設の需要が急増している。入所 型社会福祉施設の入所者約 145 万人のうち 8 割以上が 65 歳以上の高 齢者であることが 2010 年度国勢調查 ${ }^{11}$ で明らかになっており、高齢 者施設における室内環境の現状把握と改善策は喫緊の課題と言える。 近年は政府の施策による地域包括ケアシステムの構築など小型化・分 散化も進められているが、入所型の中大規模施設はより重度の要介護 度の高齢者が対象となる傾向にあり、心身状態や健康状態も異なる。 一方、入所型高齢者福祉施設の入所者は要介護度の高い高齢者が多 く、環境調整力や代謝が低下しているため室内温熱・換気の調節と管 理は極めて重要である ${ }^{2)-4)}$

しかしながら、高齢者施設における環境衛生の維持管理に対しては その法的根拠がないため、行政からの立ち入りや介入が難しく、いく つかの先行研究 ${ }^{5)}$ - ${ }^{16)}$ があるものの、施設運用と室内環境の実態など その全貌には明らかでない部分が多い。

本研究では全国の特別養護老人ホーム（以下、特養）を対象に、施 設の設備、運営・管理状況、及び室内環境に関する管理や配慮事項に
ついて実態を把握し、高齢者施設の室内空気環境の適正な計画と運用 管理のあり方を提案することを目的としてアンケート調查及び測定 を行っている。

筆者らの既往論文「特別養護老人ホームにおける環境衛生管理の現 状と課題、保健医療科学 2014」16)では 2013 年度に全国特養を対象に 行ったアンケート調查による特養の施設及び設備概要、運営形態など について報告した。

本報では、同アンケート調查内容から、施設概要及び運営形態、冷 暖房換気設備とその管理状況及び認識に関する内容を抽出、地域特性 を考慮した分析内容を報告する。

\section{2. 研究方法}

二次医療圏データ「全国特別養護老人ホーム一覧データ」 ${ }^{17)}(2011$ 年 4 月現在）を活用し、2013 年 11 月〜12 月に渡って郵送によるアン ケート調查を行った。設問対象は施設管理者や担当者である。有効発 送数 5,878 に対し 767 票（13.0\%）の有効回答を得た。

調査項目は、所在都道府県、設置・運営主体、施設規模、定員、

\footnotetext{
* 国立保健医療科学院生活環境研究部 主任研究官·博士 (工学)

$* *$ 国立保健医療科学院生活環境研究部 上席主任研究官・博士 (工学)

*** 国立保健医療科学院 統括研究官・博士(工学)
}

Senior Researcher, National Institute of Public Health, Dr. Eng.

Chief Senior Researcher, National Institute of Public Health, Dr. Eng.

Research Managing Director, National Institute of Public Health, Dr. Eng. 
表 1 全国特別養護老人ホームの建築概要

\begin{tabular}{c|r|r|r|r|r|r|r|r|r|r|r|r|r}
\hline \multirow{2}{*}{ Area } & \multicolumn{4}{|c|}{ 床面積 } & \multicolumn{4}{|c|}{ 専用フロア数 } & \multicolumn{4}{|c|}{ 築年数 } & 改修·改築 \\
\cline { 2 - 16 } & Mean & S.D. & $90 \%$ ile & 10\%ile & Mean & S.D. & $90 \%$ ile & 10\%ile & Mean & S.D. & $90 \%$ ile & 10\%ile & 割合 [\%] \\
\hline \hline I & 3213 & 1814 & 5569 & 1538 & 1.7 & 1.0 & 3 & 1 & 24.2 & 11.3 & 39.2 & 7.4 & 35 \\
\hline II & 2785 & 1188 & 4524 & 1531 & 1.3 & 0.6 & 2 & 1 & 20.2 & 10.8 & 35.2 & 8.6 & 31 \\
\hline III & 3365 & 1456 & 5233 & 1728 & 1.5 & 0.7 & 3 & 1 & 17.5 & 9.6 & 32.0 & 7.0 & 36 \\
\hline IV & 3344 & 1631 & 5505 & 1631 & 2.2 & 1.1 & 4 & 1 & 17.2 & 9.4 & 32.0 & 7.0 & 34 \\
\hline V & 2674 & 1254 & 4834 & 1104 & 1.4 & 0.9 & 2 & 1 & 19.0 & 12.3 & 37.8 & 5.0 & 36 \\
\hline VI & 2275 & 1780 & 4034 & 1517 & 1.7 & 0.6 & 2 & 1 & 27.8 & 5.7 & 33.0 & 21.0 & 50 \\
\hline \hline 全国 & 3273 & 1576 & 5312 & 1607 & 2.0 & 1.0 & 3 & 1 & 18.0 & 9.9 & 33.0 & 7.0 & 34 \\
\hline
\end{tabular}

居室概要、利用者数、利用者の特性 (要介護度)、暖房 - 冷房 - 換気 設備形式、温熱空気環境の管理状況（設定基準、管理体制）、臭気の 状況と対策、感染症の発生状況、温熱空気環境に関する配慮事項等で ある。

本報では、設問項目の中から、施設の建築及び運用の概要、冷暖房 換気設備、温湿度・換気の管理状況及び認識に関する項目を抽出・解 析した。更に、全国的な解析に加え地域別特性を調べた。

地域区分には経済産業省・国土交通省「エネルギーの使用の合理化 に関する建築主等及び特定建築物の所有者の判断の基準」 ${ }^{18)}$ の 6 地域 区分を採用した注 ${ }^{11}$ 。地域区分は、山間部や沿岸部といった特徵的な 地形が気候に与える影響を考慮して、市町村単位別となっているが、 本調査では匿名性に配慮して所在都道府県の記載しか求めなかった ため、都道府県庁所在地で簡易区分を行った。統計解析には SAS-JM P 5.0.1を用い、単変量及び地域区分との相関を見る二変量解析を行っ た。なお、重複回答を許しているため比率の合計が必ずしも $100 \%$ に ならない場合がある。

\section{3. 調査対象施設の概要及び属性}

県別回収率は 4.8\% (滋賀県) から 25.6\% (山形県) までばらつく が、全都道府県を網羅した。省エネルギー地域区分（暖房度日・気候 による区分）による有効回答の割合は「地域 $5.6 \%$ 、I 地域 $2.5 \%$ 、 III 地域 15.3\%、IV-a 地域 17.1\%、IV-b 地域 50.2\%、V 地域 8.7\%、VI 地域 $0.5 \%$ 」゙あった。但し、VI 地域（沖縄県）は回答数 4 件と統計 的な意味をなさないが、他地域と区別できる特徵を呈していることも あるため、本論文では参考值として記載する。

全体結果から、入所定員は平均 71 人、実際の利用者数 70 人、職員 数 47 人、利用者の要介護平均は 3.9 と「最重度な介護が必要な状態 (要介護 4)」にあることが分かった。

\section{1 建築概要}

調查対象施設の概要及び属性を表 1 に示寸。平均築後年数は 18 年 (S.D.9.9) であるが、改修・改築があった場合その年を基準にすると 平均 12.7 年 (S.D.9.2) と、多くの施設が改修・改築期を迎えている ことがうかがわれる。I、II、VI 地域は平均築年数約 20 年以上と他の 地域より古いが、III、IV、V 地域は比較的に新しく建てられる施設が 多いと見られる。改修・改築工事を行っていると答えた施設は地域に かかわらず 3 割以上と地域偏差は大きくない。

特養部分の延床面積を図 1 に示寸。平均面積は $3,273 \mathrm{~m}^{2}$ (S.D. 1,576)、 地域別ではII、V、VI 地域が平均 $3,000 \mathrm{~m}^{2}$ 未満であったが、I、III、 IV 地域は 3,000 $\mathrm{m}^{2}$ を超え 90 パーセンタイル值も $5,000 \mathrm{~m}^{2}$ を超えて

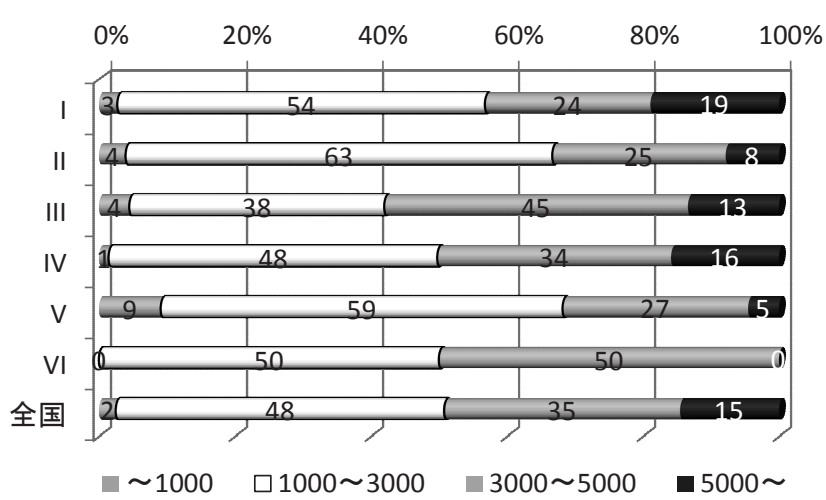

図 1 延床面積

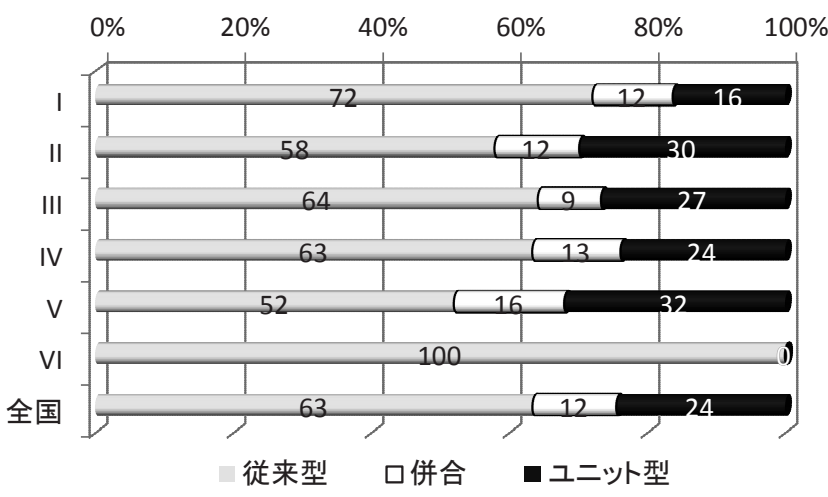

図 2 施設形態

いた。建築物衛生法の適用対象に社会福祉施設は含まれないが、同法 で対象としている特定建築物は専用面積 $3,000 \mathrm{~m}^{2}$ 以上を面積基準とし ており、特養もかなり大きな規模を有していることが分かる。また、 図表には示さないが、建物構造は約 9 割が鉄筋コンクリート造、平均 階数は 2.6 であり 3 階建以下の低層が 8 割を占める一方、特養部分の 専用フロア数は平均 2.0 (S.D.1.0) と施設の特性上、立面的に低く平 面的に広い構造となっているが最大 9 フロアを有する施設も存在し ていた。

\section{2 施設運営形態}

運営形態は民設民営が約 8 割、公設民営が約 1 割、公設公営が $6 \%$ と、I〜III 地域は IV〜VI 地域より公設が多い。施設管理において環 境衛生管理業務を専門業者に委託している施設は 34\%あった。また、 業者委託有無に関わらず施設内で専任または兼任の担当者を決めて いる施設が $71 \%$ あった。一方、専門業者に委託すると共に施設内に 
担当者を決めている施設が $23 \%$ 、専門業者委託一施設内担当者はい ないが $10 \%$ 、専門業者委託無し一施設内担当者がいる施設が $43 \%$ 、 委託も担当者もない施設が $24 \%$ 存在した。環境管理の配慮・工夫や 感染症対策には 9 割以上が取り組んでいた。

施設形態（図 2）は従来型が $64 \%$ 以上、ユニット型 $24 \%$ 、併設型 も $12 \%$ ある注2)。2000 年以降国策によるユニット型への移行が進めら れていることから、建築年度を 2000 年以前と以降に区分すると 2000 年以前は従来型が 8 割以上、ユニット型は $3 \%$ のみだったが、2000 年 以降に建てられた施設は $56 \%$ がユニット型に移行し従来型は $34 \%$ ま で縮小していた。一方、従来型とユニット型を併設している施設の割 合も $12 \%$ 程度と依然と多床室への需要は根強く残っていることが分 かる。II、III、IV、V 地域は従来型が 5 割〜6 割程度であるが、I 地域 は 7 割以上が従来型で平均築年数 (24.2 年) からも他の地域より断然 高く、老朽化が進んでいる。一方、V 地域はユニット型と併合型が $48 \%$ と半数に近く、他の地域よりユニット型化が進んでいる。V 地域 は築年数からも新しい施設が多いため、新設や増改築が進められてい ると考えられる。

\section{4. 冷暖房換気設備}

冷暖房換気設備に関する設問の有効回答率は 99.1\%（760/767）で あり、結果の詳細について図 3〜図 5 にまとめた。グラフにてBed は 居室（Bedroom）、Com は共用室（Common space）である。

\section{1 暖房}

図 3 に地域別暖房設備の設置状況を示寸。寒い地域ほど中央式暖房 設備の割合が高い傾向にあり、III地域から個別式が増加している。 関東圈を含む最も広い地域が属するIV 地域までは中央式と個別式が 半分程度ずつを占めているが、V、VI 地域になると中央式が激減して いることから、全館暖房を行わなくても対応できる気候にある地域は 個別式のみで対応していることが分かる。また、中央式と個別式を併 用している施設は居室で 17\%、共用室で 15\%あった。

図 4 に個別式暖房機器の内訳を示す。暖房で個別式を使用している との回答中、どのような個別機器を使用しているかについて、居室で は 95\%がエアコン、床暖房 13\%、密閉・半密閉型ストーブ 1\%、開 放型ストーブ 1\%であり、個別式暖房を使用している施設の $15 \%$ がそ れらの機器を二種類以上併用していると答えた。

共用室ではエアコン $93 \%$ 、床暖房 24\%、開放型ストーブ 3\%、電 気ストーブ・炬燵 2\%、いずれかを併用しているが 26\%であった。

\section{2 冷房}

冷房設備（図 5）について全国平均からは居室 6\%、共用室 4\%に 設置していないと回答した施設が存在したが、। 地域（北海道）のよ うな夏期に酷暑日が殆ど現れない地域からの回答であった。個別式を 設置している施設は居室 56\%、共用室 48\%、中央式が居室 $25 \%$ 、共 用室 $37 \%$ と共用室に中央式空調が設置されていると答えた施設が多 かった。また、居室 $12 \%$ 、共用室 $11 \%$ に中央式と個別式を併用して いると答えた施設があった。

I 地域は居室の $79 \%$ 、共用室の $59 \%$ に冷房設備が設置されていない。 II 地域も居室 16\%、共用室 11\%の無冷房が存在するが II 地域からは 冷房設備がない施設は僅かとなる。また、暖房に比べて居室と共用室 における設備タイプの違いが顕著であり、川I地域より温暖な地域で は居室の約 7 割以上に個別式が設置されている。

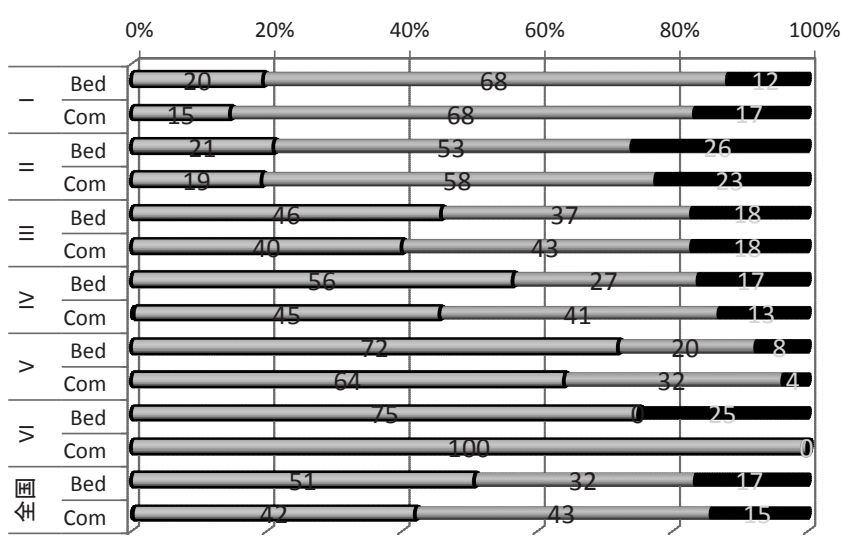

$\square$ 無し、個別、中央、併用

(Bed：居室 / Com：共用室）

図 3 暖房設備

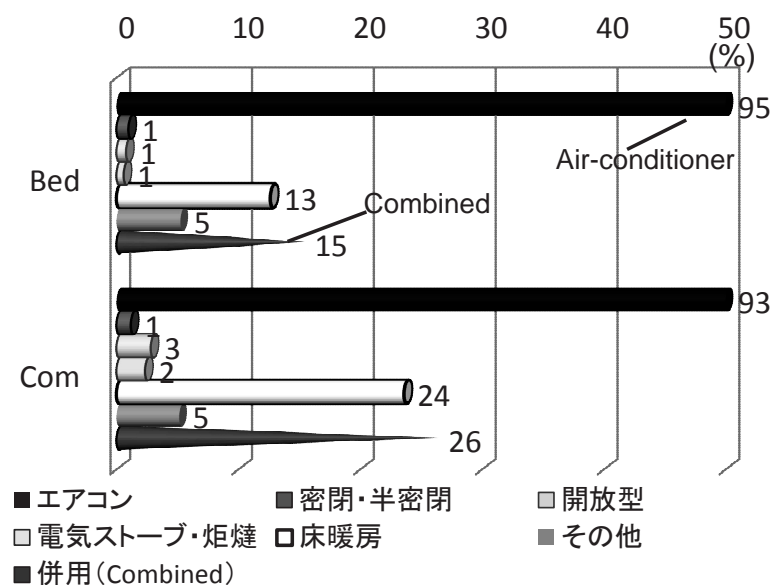

図 4 個別式暖房器具の内訳

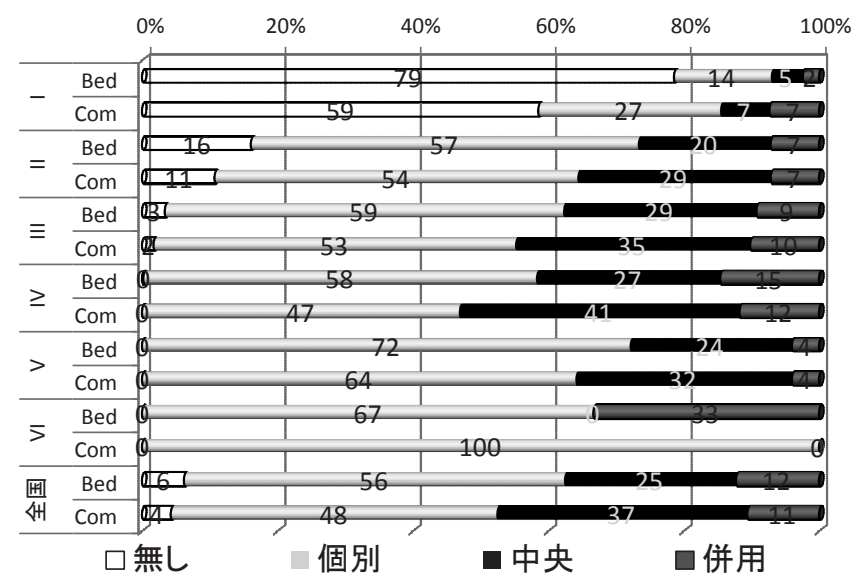

図 5 冷房設備

全体的には居室が共用室より個別冷房が多く、高効率運転に有利で小 回りの利く個別式冷房装置が増えている。中央・個別式を併用してい ると答えた施設は、居室で 11\%、共用室で12\%あった。

\section{3 換気}

図 6 に換気設備方式について示す。全国平均から、居室においては 中央式換気設備 $17 \%$ 、ハイブリッド式 (機械・自然換気複合式) $9 \%$ 、 
換気扇 69\%、無し 5\%、共用室は中央式 20\%、ハイブリッド式 10\%、 換気扇 $64 \%$ 、無し $5 \%$ と、いずれの室においても個別換気扇が 6 割以 上の高率を占めた。II 地域を除いて中央式の導入率は居室・共用室で 2 割程度で、II地域のみ 7\%と低い。一方、ハイブリッド式は। 地域 が 16\%で、他の地域の10\%前後より多少高い。寒冷地域であるため 放射式暖房が採用されている割合が高いことや冬期の換気による室 温低下などを考慮した熱交換型換気設備が導入されている割合が他 の地域より高いと考えられる。そのため、I 地域では換気扇は居室・ 共用室共に $50 \%$ 未満であり、他地域平均の居室 $72 \%$ 、共用室 $62 \%$ よ り低かった。また、換気設備が無いと答えた施設もI地域の割合が高 かった。

\section{5. 室内環境の管理基準}

図 7 に温度・湿度・換気の管理基準設定率の全国平均を、図 8 に地 域別設定率を示す。夏期および冬期の温度については居室 $62 \%$ 、共 用室 $63 \%$ に基準を設けていた。湿度は、夏期が居室・共用室共に $27 \%$ 、冬期においては居室 $44 \%$ 、共用室 $43 \%$ と、温度基準は設け ているが湿度基準は持っていない施設が多数存在している。冬期の湿 度基準を設定している施設が夏期に比べて約 6 割多い。換気基準に関 しては、夏期に居室 32\%、共用室 30\%、冬期 38\%及び $36 \%$ と冬場 の割合が高かった。

\section{1 温度管理基準}

温度管理基準において、夏期温度基準は居室・共用室ともに温暖な 地域ほど管理基準を設けている割合が高くなる傾向を示し、冬期にお いても同様の傾向にあった。全国的には夏期・冬期ともに 6 割程度の 施設が管理基準を設けていた。相対的に涼しいI地域は約 2 割の施設 のみが夏期管理基準を設けていると答えたが、II 地域は約 5 割、III・ IV 地域は 6 割以上があると回答し、V 地域は 7 割まで高くなる。夏 期の気候が厳しい地域ほど温度管理に気をつけていることが分かる。 一方、冬期管理基準に対しても温暖な地域ほど基準を持っている施設 が多い結果となった。

夏期の温湿度基準值について回答した施設（452 件）について、居 室の温度管理基準值は $17 \sim 30^{\circ} \mathrm{C}$ (平均 $26.1^{\circ} \mathrm{C} 、 S . D .2 .2$ )、相対湿度は 20 $80 \%$ RH（平均 54\%RH、S.D. 10.8）と幅広く分布している。共用 室においてもほぼ全施設で居室と同様な管理基準を設けていた。

最低温度基準を $24^{\circ} \mathrm{C}$ 以下と回答した施設は 37 件（8\%）と管理基 準を設けている施設の 9 割以上が $24^{\circ} \mathrm{C}$ 超える範囲で基準值を設定 していた。詳しくは、 $24^{\circ} \mathrm{C}$ 以上 $26^{\circ} \mathrm{C}$ 以下が 90 件 $(20 \%) 、 26^{\circ} \mathrm{C}$ 上上 $28^{\circ} \mathrm{C}$ 以下は 308 件 (68\%) であり、最高基準温度としては $28^{\circ} \mathrm{C}(249$ 件、55\%）が最も多かった。

冬期の温湿度基準值について回答した施設（464 件）について、居 室は $15 \sim 32^{\circ} \mathrm{C}$ (平均 $22.8^{\circ} \mathrm{C} 、$ S.D.2.6) 、湿度 $20 \sim 80 \%$ RH（平均 $51 \%$ RH、S.D.10.4) であった。

$18^{\circ} \mathrm{C}$ 末満と答えた施設が 17 件 $(4 \%)$ と、殆どの施設が $18^{\circ} \mathrm{C}$ 以上 を最低温度としている。 $20^{\circ} \mathrm{C}$ 以上 $22^{\circ} \mathrm{C}$ 未満が 136 件（29\%）、 $22^{\circ} \mathrm{C}$ 以 上 $24^{\circ} \mathrm{C}$ 未満が 148 件 $(32 \%) 、 24^{\circ} \mathrm{C}$ 以上が 113 件 $(24 \%)$ と $20^{\circ} \mathrm{C}$ 以上 が $86 \%$ と施設の多くが $20^{\circ} \mathrm{C}$ 以上を最低温度としている。

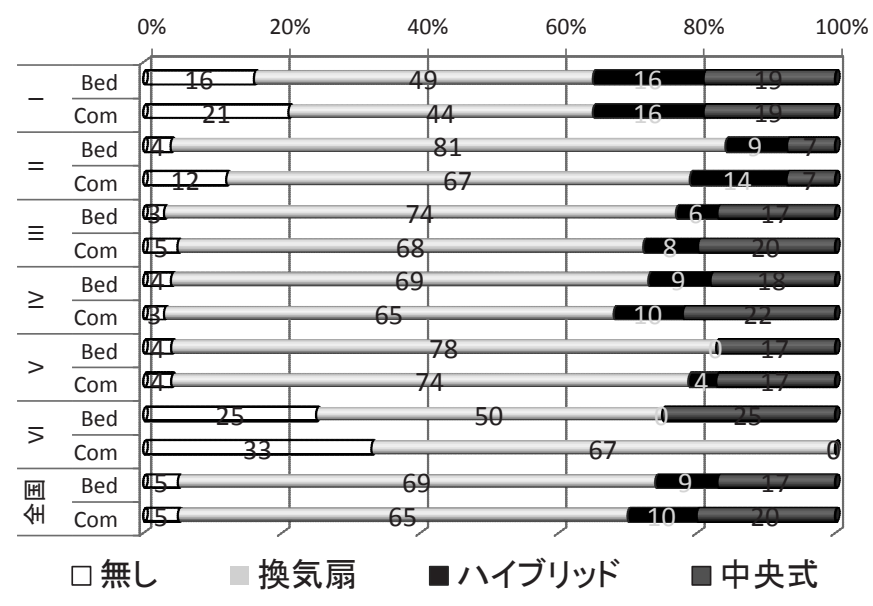

図 6 換気設備

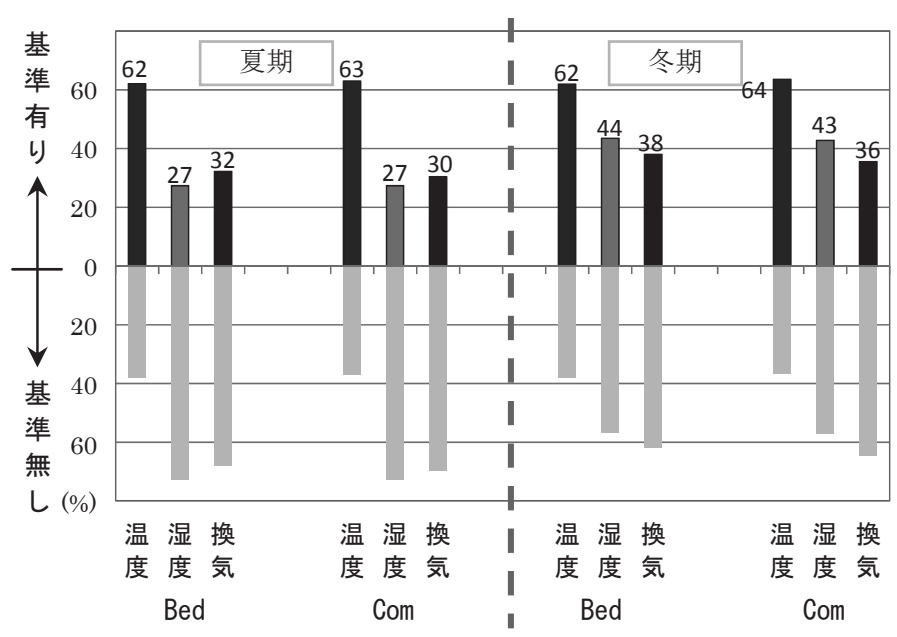

図 7 温度 $\cdot$ 湿度 - 換気の管理基準（全国）

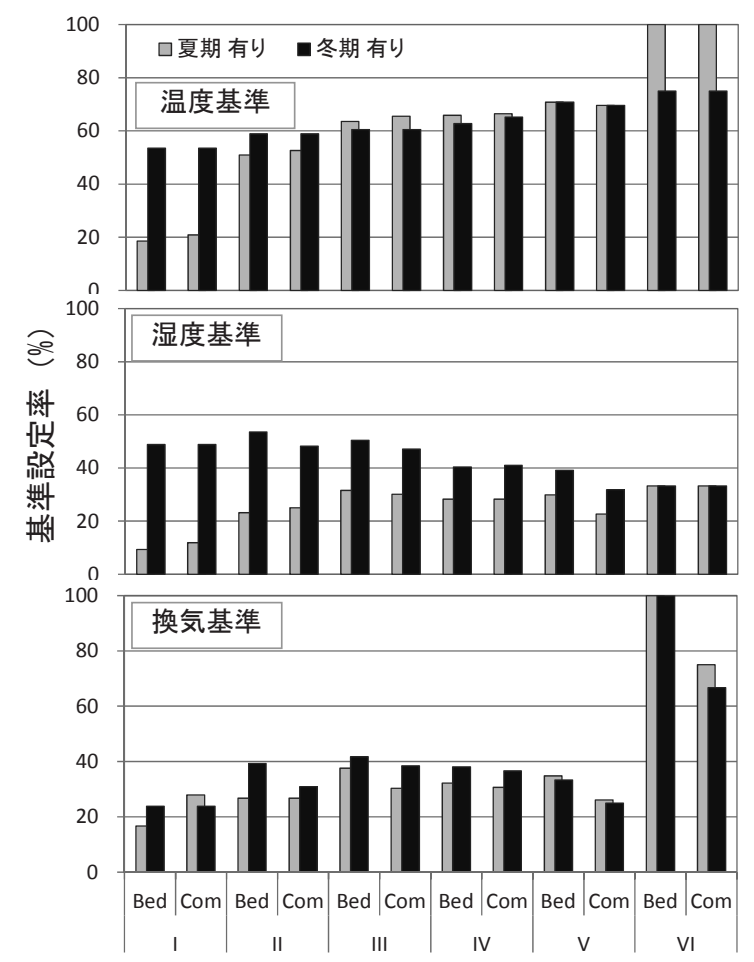

図 8 温度 ・湿度・換気の管理基準（地域別） 
省エネルギーの観点から推奨されている冬期 $18^{\circ} \mathrm{C}$ は高齢者施設で は低いという認識が強いことがうかがわれるが、少数ではあるものの $18^{\circ} \mathrm{C}$ 若しくはその未満と回答した施設も存在し、高齢者の温度環境に 対する認識が十分でない施設があった。

\section{2 相対湿度管理基準}

湿度管理基準は全国平均で夏期 27\%、冬期 43〜44\%の施設が設け ており冬期により気をつけていたが、温度基準に比べると低い。特に 冬場の感染症流行に気を使っているため湿度調節への意識は高いも のの実際に基準を設けて管理している施設は少ないことが明らかと なった。

夏期湿度基準は、最低值を $40 \% \mathrm{RH}$ 未満と回答したのは 6 件 (1\%)、 最高値 70\%超が 5 件（1\%）あったものの、ほとんどの施設で 40\%〜 70\%を基準值範囲としていた。冬期は、最低值を 40\%RH 未満が $6 \%$ 、 最大值 70\%RH 超過が 1\%で、ほとんどの施設は 40 70\%RH の間で 設定していた。

一般的には外気の絶対湿度が低く低湿度への対策が講じられる冬 期の管理基準設定率は $\mid$ ・| の寒冷地域が高い傾向が見られた。一方、 夏期における管理基準は|・|| 地域が低く冬期と逆の傾向が見られた。

\section{3 換気管理基準}

換気管理基準を設けている施設は夏期が 3 割強、冬期は 4 割弱と全 般的に低く、乾燥や空気感染症が発生しや寸い冬期が若干高い。基準 が無いと答えた施設は、I 地域の夏期において居室 83\%・共用室 72\%、 冬期は居室・共用室共に 76\%に対して、他の地域の平均は夏期居室 67\% ・ 共用室 70\%、冬期居室 61\% ・ 共用室 64\% とI 地域の基準設定 割合が多少低かったが、地域と管理基準に有意な相関は認められなか った。

換気管理基準の詳細を図 10 に示す。換気調節の全国平均について、 「規則的に換気を行っている」が居室・共用室 45\%、「においが気に なった時に行う (以下、気になった時)」が 34\%、31\%、「気づいた時 に行う」が 43\%、46\%あった。規則的な換気を除く「気になった時」 「気づいた時」のみ換気を行うという回答は居室 52\%・共用室 54\% であった。一方、規則的に換気を行っていると答えた施設の多くは、 気になった時や気づいた時にも換気を行っていると答えていた。

地域別には、「規則的」と回答したのは、।・川 地域が約 22〜36\%で あったが、その他の地域は 4 割以上であった。その反面、規則的な換 気ではなく「気になった時」「気づいた時」のいずれかによる換気は、 寒冷地域の|・|| 地域で 63～79\%でありその他地域の 45～59\%より高 かった。「規則的に換気を行っている」かつ換気頻度について回答が あった施設を対象に 1 日の換気頻度について調べた。

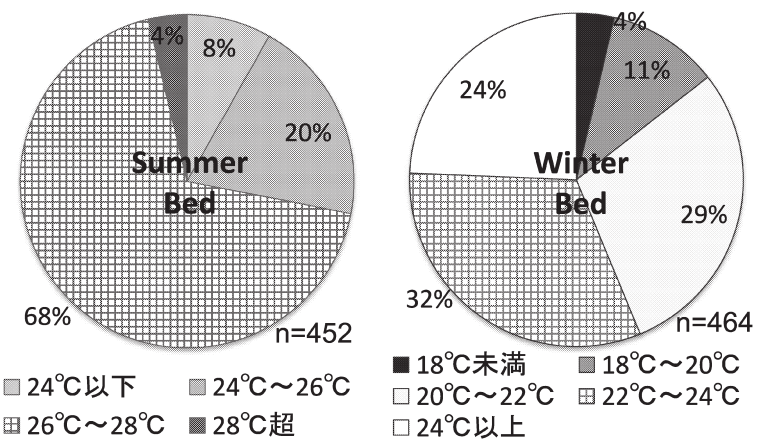

図 9 温度設定値（居室）

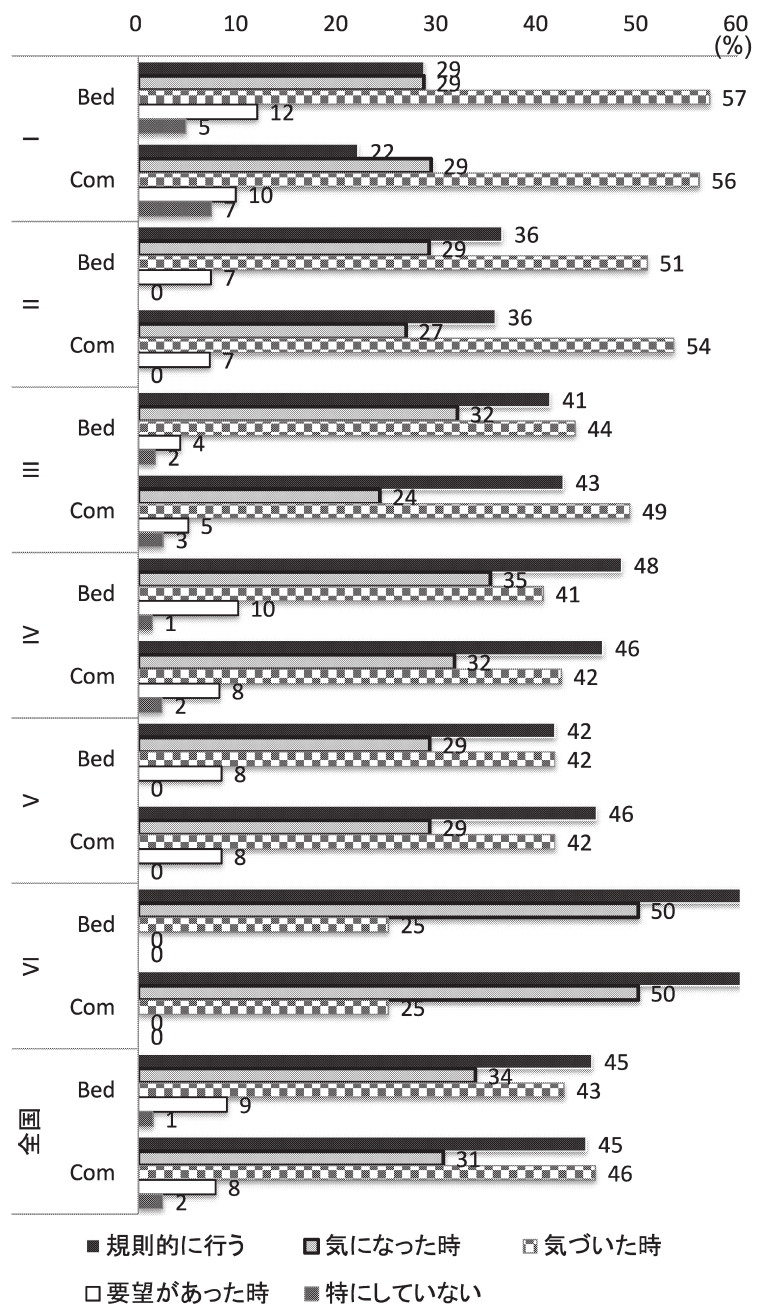

図 10 換気管理基準の詳細
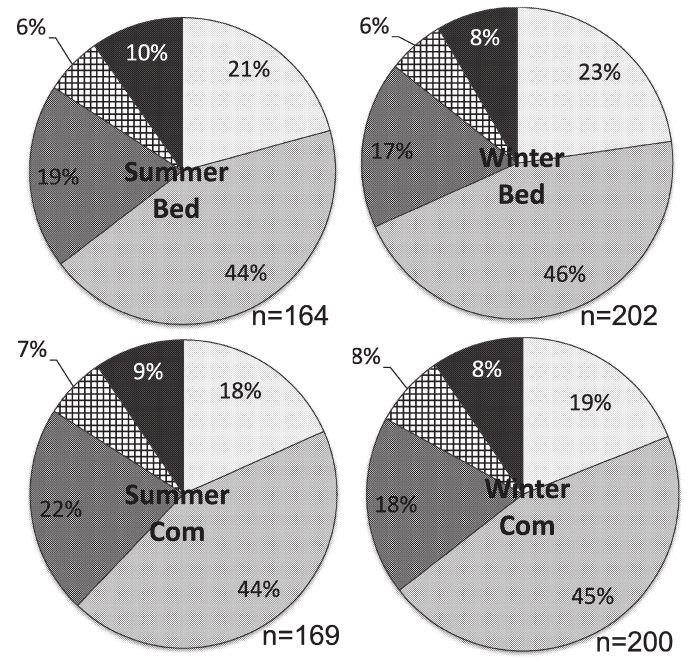

$\square$ 1回以上 2回未満 $\square$ 2 3回未満

口3 4回未満 \#4回以上

-24時間換気

図 11 1日当たり換気頻度（換気管理基準有りのみを対象）

1 日当たり換気頻度を図 11 に示す。夏期において、居室の場合は 1 ～2 回 21\%、2 3 回が 44\%、3 回以上は 25\%であり、24 時間常時換 気を行っている施設は 10\%あった。共用室も居室と大きな違いはな 
かった。

冬期に対して、1〜2 回と答えたのは 23\%、2〜3 回が 46\%、3 回以 上計画的に行っていたのは $23 \% 、 24$ 時間常時換気を行っていると答 えたのは 8\%であり、共用室も居室と大きな違いはない。一方、夏期 より 3 回未満の回答が $4 \%$ 増えたが、 3 回以上及び 24 時間換気はやや 減少している。

\section{6. 考察}

\section{1 冷暖房換気設備}

空調設備全般においては、中央式より個別式の割合が高く、共用室 には居室より中央式が設置されている割合が冷房・暖房共に 10\%程 度高かった。中央・個別式を併用していると答えた施設の割合は、冷 房より暖房で 4〜 5\%程度高く、冬期の寒さに対する対策がより求め られていると考えられる。

暖房において、中央式と個別式の併用は居室 17\%、共用室 15\%で あったが、個別式暖房機器を使用している施設の中で個別機器を 2 種類以上併用しているところは $26 \%$ と個別式機器の存在が機器併用 率を高めていた。具体的には、個別式機器としては居室・共用室共に エアコンが 9 割以上、床暖房が居室 13\%、共用室 24\%を占めた。一 方、ストーブは $2 \% 、 4 \%$ と低く、高齢者施設における火災や事故防 止のための対策と考えられる。

寒い地域ほど中央式暖房設備の割合が高い傾向にあり、II 地域か ら個別式が増加していたが、これは全館暖房の採用に有利な寒冷気候 の地域境界がこの付近であることに加え、空気熱源ヒートポンプを採 用しているパッケージェアコンの効率的な運転が期待できることに 起因すると考えられる。

また、施設のユニット化に伴う居室の個室化とイニシャルコスト及 び運転コスト・省エネ・制御自由度の面から個別式空調設備の設置が 増加していると考えられる。一方、中央式空調はフィルター性能、調 湿、維持管理において優位性を有していることから、個別式空調の普 及率増加は衛生管理上の補修点検箇所が増えることに注意すべきで ある。

\section{2 温湿度に対する認識}

高齢者は温度に対する知覚・反応が鈍く温度調節能力も劣る一方、 代謝が低いため寒さに弱いことが知られている。施設側も温度に関す る基準設定率が最も高く、平均として夏期 $26.1^{\circ} \mathrm{C}$ 、冬期 $22.8^{\circ} \mathrm{C}$ と気を 配っていることがうかがわれるが、基準範囲が夏期 17 30 ${ }^{\circ} \mathrm{C}$ 、冬期 15〜 32 $2^{\circ} \mathrm{C}$ 認識に問題がある施設も見られる。また、夏期クールビズ や冬期省エネルギーでよく詔われる $28^{\circ} \mathrm{C}$ や $18^{\circ} \mathrm{C}$ に影響を受けている 施設も少なくなく、建築物衛生法における $17^{\circ} \mathrm{C} \sim 28^{\circ} \mathrm{C} 、 40 \sim 70 \% \mathrm{RH}$ といった特定建築物の室内環境基準を念頭に置いている施設もある ように見える。しかし、建築物衛生法は多数が利用する室内、つまり オフィス・商店・興行場などに適用されるものであり、高齢者のため の室内環境管理基準ではない。高齢者に見合う温度条件は健常者とは 異なることを十分認識した上で、管理基準を運用する必要がある。

温度管理基準は夏期・冬期ともに全国平均 6 割程度の施設が管理基 準を設けているが、湿度基準は全国平均で夏期は居室・共用室共に 27\%、冬期居室 44\% ・ 共用室 43\% と温度基準に比べて低い。冬期の 湿度基準を設定している施設が夏期に比べて約 6 割多く、冬期におけ る風邪やインフルエンザのような感染症防止に気を付けていること
がうかがわれたが、温度に比べて感知しにくいことや分かりやすく表 示される湿度計の普及が少ないこと、また冬場加湿の難しさなどが湿 度管理基準を低くしていると推察される。

III、IV、V 地域のような夏期の気候が厳しい地域ほど温度管理に気 をつけており、冬期に対しても温暖な地域ほど基準を持っている施設 が多い結果となっている。I地域は夏期に比較的過ごしや寸い気候で あるため、冬期の暖房により気をつけているが、外気条件が厳しい冬 期であっても全館暖房や床暖房に加え常に一定な室内温度を維持す ることが当然であるためむしろ管理基準が定まっていない可能性が ある。対流式暖房、個別式空調の割合が高い温暖地域では空気乾燥に よる問題や個別制御の面でも温度管理への意識が高いと推察される。

温度管理基準は温暖地域になるほど基準を設けている施設が増え る傾向にあるが、湿度管理基準は夏期が 3 割未満で低く、その中でも I 地域が 10\%程度と他の地域より低い以外、地域別に特徵的な傾向は 見えない。しかし、冬期湿度管理基準は寒い地域ほど高く、外気の絶 対湿度が低いことと感染症予防、乾燥感や感染症防止に対する意識な どが影響していると考えられる。

\section{3 換気に対する認識}

全国的に換気設備は換気扇が 7 割以上、中央式が約 2 割と換気扇の 設置率が高いという回答となった。一方、冷暖房設備で中央式と答え た施設数に比べ、換気設備では中央式と答えた割合が半減している。 全館床暖房のような施設も含まれているため、ここでの違いが全て認 識の間違いから生じたものではないが、一部施設管理者は設備への知 識や認識に問題がある可能性が考えられる。

II・III 地域の中央式換気設備が他の地域より低く、I地域では換気 扇がないと答えた施設が他の地域より多かったが、I地域の場合は熱 交換器の普及が進んでおり専門知識を持たない管理者はこれを換気 装置として認識できていない可能性も考えられる。

換気管理基準を設けている施設も夏期 3 割、冬期 4 割弱と閉め切っ た生活になりや寸く空気感染のリスクが高まる冬期の管理基準設定 率が多少高くなる。換気調節の全国平均について、「規則的に換気を 行っている」施設が半分近くあったが、「気になった時」「気づいた時」 のみ換気を行うという回答は 5 割以上と任意的に行うとの回答が多 少多い。高齢者の日常生活における配慮事項として、温度環境が空気 清浄度に優先していることが読み取れるが、においや空気の停滞感を 解消寸るにはやはり空開け換気を行う必要があることもうかがわれ る。

規則的な換気を行っている施設は気になった時や気づいた時にも 換気を行うと回答している割合が高く、換気により配慮している傾向 が見られる。

寒冷地域である। 地域は他の地域に比べて基準設定割合が低く、 「規則的に行う」施設の割合も全国で最も低い反面、「気になった時」 「気づいた時」に行うと答えた割合は最も高い。寒冷気候での空開け 換気による温熱不快感が原因と考えられ、規則的に行うよりは排泄介 助や体臭など介護スタッフがにおいを気にする時に空開け換気を行 っていることが読み取れる。

「規則的な換気を行っている」と答えた施設の中で、24 時間常時 換気と答えた施設は約 1 割と少なく、1 日に行う換気の頻度は 2 回以 上 3 回未満が 4 割以上と最も多い。次に 1 回以上 2 回未満が 2 割強、 3 回以上 4 回未満が 2 割弱であり、1 回以上 3 回以下が全体の 8 割以 
上を占めている。夏期・冬期のような外気条件が厳しい時期の換気の タイミングとしては、排泄介助のにおい発生時、食事・入浴など高齢 者が居室を離れる際が考えられる。

\section{4 地域特性}

地域区分（気候区分）を説明変数として専用フロア数、延床面積、 施設形態、冷暖房方式、換気方式、温度・湿度・換気管理基準の有無、 換気頻度に対して相関分析を行った。

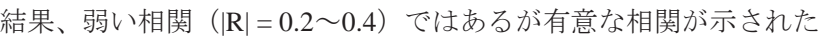
項目は、施設専用のフロア数、冷房方式_個室、冷房方式_共用室、温 度管理基準_夏期_居室、温度管理基準_夏期_共用室の 5 項目であった。 地域区分と専用フロア数の関係では、I 地域から VI 地域に行くに つれフロア数が多くなる正の弱い相関（ $|R|=0.21 ）$ が見られ、その相 関に有意差も認められる結果となったが、これは相対的に規模が大き く施設数も多いIV、V 地域の寄与が大きいことが原因である。

一方、施設の延床面積を $1,000 \mathrm{~m}^{2}$ 未満、1,000 3,000 $\mathrm{m}^{2}$ 未満、3,000 $\sim 5,000 \mathrm{~m}^{2}$ 未満、 $5,000 \mathrm{~m}^{2}$ 以上と順序尺度に変換して相関分析を行った 結果、気候による地域区分との相関は見られなかった（ $|R|<0.1$ 、 $\mathrm{p}=0.4876>0.05$ )。

地域と施設形態の相関に関してはI地域から VI 地域に（温暖気候 に）なるにつれ従来型よりユニット型が増える傾向が見られたが、相 関性及び有意差は認められなかった（ $|R|<0.1 、 p=0.7288>0.05 ） 。$ ユ ニット型になるほど床面積が大きくなる傾向を示しているが、これは 施設形態によるものというよりは建築年が新しく大規模化している ことに起因すると考えられる。

泠暖房方式に対して、冷房方式は個室（ $p<0.001 、|R|=0.32 ） \cdot$ 共用 室（ $p<0.001 、|R|=0.26 ）$ ともに弱い正の相関があり、その有意差も 認められた。暖房方式は負の相関の傾向が見られたが、有意差は認め られなかった。換気方式では有意な相関は示されなかった。

夏期の温度管理基準は居室 $(p<0.001 、|R|=0.22)$ 、共用室 $(p<0.001$ 、 $|R|=0.33)$ ともに弱い相関ではあるが、地域との有意な相関が得られ た。冬期の温度管理基準においては共用室基準が有意差が認められた がその決定係数は低く相関関係は見いだされなかった。「6.2 温湿度 に対する認識」にて言及しているが、この解析結果は夏期・冬期に関 わらず夏期の気候が厳しい地域ほど温度管理に気をつけていること を裏付けている。

湿度管理基準では居室における管理基準が夏期・冬期ともに有意差 が認められたものの決定係数は小さく（|R|<0.1）相関関係は見いだ されなかつた。

地域区分と換気管理基準の設定有無との関係からは、換気基準_夏 期_居室が I 地域から V・VI 地域になるにつれ設定率が高くなる傾向 を示し、有意差（ $p=0.04<0.05 ）$ も認められたが、相関はなかった

$(|R|<0.1)$ 。他の条件に関して有意差は認められなかった。

「規則的に換気を行う」の回答をした施設における 1 日の換気頻度 を「1 回以上 2 回未満、 2 回 3 回未満、3 回 4 回未満、 4 回以上、 24 時間常時換気」の 5 区分にし、地域差による違いについて相関分 析を行った結果、夏期・冬期ともに有意な相関が認められたものはな かつた。

\section{7. まとめ}

全国特養の床面積平均は $3000 \mathrm{~m}^{2}$ 以上、築年数 18 年、改修・改築し
表 2 地域区分による相関分析結果

\begin{tabular}{|c|c|c|}
\hline 項 目 & $p$ 值 & $\mathrm{R}$ | \\
\hline 用途_単独・複合 & 0.0370 & 0.08 \\
\hline 施設形態（従来・ユニット） & 0.7288 & 0.01 \\
\hline 建物の総階数 & $<.0001 * * *$ & 0.19 \\
\hline 施設専用のフロア数 & $<.0001 * * *$ & 0.21 \\
\hline 延床面積 & 0.4876 & 0.03 \\
\hline 築年数 & $0.0001 * * *$ & 0.14 \\
\hline 冷房方式 個室 & $<.0001 * * *$ & 0.32 \\
\hline 冷房方式－共用室 & $<.0001 * * *$ & 0.26 \\
\hline 暖房方式_居室 & $<.0001 * * *$ & 0.18 \\
\hline 暖房方式－共用室 & $<.0001 * * *$ & 0.19 \\
\hline 換気方式—居室 & 0.2996 & 0.04 \\
\hline 換気方式－共用室 & $0.0330 *$ & 0.08 \\
\hline 温度基準_夏期_居室 & $<.0001 * * *$ & 0.22 \\
\hline 温度基準_夏期_共用室 & $<.0001 * * *$ & 0.33 \\
\hline 温度基準_冬期__居室 & 0.1199 & 0.06 \\
\hline 温度基準_冬期_共用室 & $0.0471 *$ & 0.07 \\
\hline 湿度基準_夏期_居室 & $0.0320 *$ & 0.08 \\
\hline 湿度基準_夏期_共用室 & 0.1008 & 0.06 \\
\hline 湿度基準_冬期_居室 & $0.0216 *$ & 0.08 \\
\hline 湿度基準_冬期_共用室 & 0.0736 & 0.07 \\
\hline 換気基準_夏期_居室 & $0.0400 *$ & 0.08 \\
\hline 換気基準_夏期_共用室 & 0.4126 & 0.03 \\
\hline 換気基準_冬期_居室 & 0.2671 & 0.04 \\
\hline 換気基準_冬期_一共用室 & 0.1886 & 0.05 \\
\hline
\end{tabular}

$\left(* \mathrm{p}<0.05 、{ }^{* *} \mathrm{p}<0.01 、{ }^{* * *} \mathrm{p}<0.001\right)$

た施設も 3 割以上であることが示された。従来型が 6 割以上を占めて いる中、2000 年以降に建てられた施設はユニット型化が進んでいる が多床室への需要は依然と高く、従来型とユニット型を併設している 施設も多い。また、I、III、IV 地域はその他地域より施設規模が大き い傾向にあったが省エネルギー基準による地域区分と施設規模間に 相関はなく、新しい施設ほど大規模になる傾向が見られた。

地域（気候）及び建築年度による冷暖房・換気設備の違いが現れる のは当然のことで、本研究でもそのような傾向が確認された。

施設のユニット化に伴う居室の個室化と初期及び運転コスト・省エ ネ・制御自由度の面で有利な個別式空調設備の導入が増加しているが、 中央式空調の長所と言えるフィルター性能、調湿、維持管理の面から 個別式空調の普及率増加は衛生管理上の補修点検箇所が増えること に注意すべきである。

室内の温度管理基準は約 6 割の施設が設けているが、湿度及び換気の 管理基準を持っている施設の割合は低く、空気質環境入関心を持って いながらも対策や励行に対する認識は高くないことがうかがわれた。 地域区分と冷房方式及び夏期の温度管理基準に相関関係が得られた ことから、夏期の気候が全体の温度管理に影響していることが分かっ た。管理基準を設けている施設は常識的な範囲内での設定が多かった が、健康・快適の面から望ましくない值を報告した例も見られた。温 湿度、換気基準の季節別の違いから冬期における感染症に気を付けて いる施設が多く、省エネルギーに対する認識も持っている施設が多か った。

特別養護老人ホーム入所者の多くが要介護度の高いハイリスク者 であり、施設側も室内環境管理や感染症対策には関心が高く実際に取 
り組んでいるものの一部の施設ではその体制に問題がうかがわれる ことがあった。例えば、設備運用や管理を外部業者に委託して設備状 沉や運用実態は把握できていない、また換気設備への知識や認識に問 題があることがうかがわれる施設管理者も存在している。

施設運用を指揮・監督する管理者の認識は施設環境全体を左右する ことから、誤った情報や認識は高齢者の健康衛生のリスクに繋がる可 能性があるため、施設管理者並びに介護職員に対する設備や室内環境 に関する教育や情報提供を行ってゆくなど効果的な保健衛生管理体 制の整備が望まれる。

本研究は「国立保健医療科学院基盤的研究費」による研究（倫理審査 承認番号 NIPH-TRN\#12016）成果の一部である。

注

注 1) 2016 年 5 月現在、省エネルギー法の改正に伴い、地域区分もより細かい 8 区分となったが、母数に限界があるため細かすぎる地域区分を採用する のは難しく、また既報との整合を合わせるために次世代省エネ基準（H11 年度）による旧地域区分 6 区分を用いた。

注 2) 厚生労働省は、「居宅に近い居住環境の下で、居宅における生活に近い 日常の生活の中でケアを行うこと、すなわち、生活単位と介護単位を一致 させたケア」と定義し、ユニットケアを提供するに当たっては「入居者が 相互に社会的関係を築き、自律的な日常生活を営むことを支援」する ${ }^{19}$ 、 としている。

簡単には、従来型は 6 名、 4 名、2 名など多床室をベースにして非特定多 数の職員が介護を行うが、ユニットケア型はリビングや共用空間を中心に 個室（1 人室）を数室から 10 室程度配置させ、同一ユニット内の入居者同 士の交流を励ますと共に、ユニット毎に担当の介護職員を決めて入所者の 生活パターン・習慣・能力などを把握して個人個人に合わせた介護を狙い とする。

\section{参考文献}

1) 総務省、平成 22 年国勢調查一人口等基本集計結果一、一人口等基本集計(男 女・年齢・配偶関係、世帯の構成、住居の状態など)第 6 表一、 http://www.stat.go.jp/data//kokusei/2010/kihon1/pdf/gaiyou1.pdf http://www.e-stat.go.jp/SG1/estat/N ewL ist.do?tid=000001039448 ～(accessed 2016.9.20)

2) 久野真矢、清水一: 文献調查から見出した高齡者施設の好ましい物理的環 境、広島大学保健学ジャーナル、Vol.3(1)、pp. 21-36、2003.

3）矢野久子、鈴木幹三 : 高齢者の冬季感染症の現状と対策一冬季における高 齢者の施設内感染症の現状と対策 高齢者施設と在宅領域の要介護高齢 者一の感染予防、Geriatric M edicine、46（11）、pp.1337 1341、2008.

4) 稲松孝思: 高齢者施設における感染症対策、INFECTION CONTROL、15(11)、 pp. 1080 1083、2006.

5) 西村直也、鍵直樹、柳宇、池田耕一、吉野博、斉藤秀樹、斉藤敬子、鎌倉 良太、小烟美知夫 : 老人福祉施設における室内環境の衛生管理に関する研 究 : 第 1 報-建築物衛生法に基づく実測調查とその結果、空気調和・衛生 工学会論文集、179、pp. 27 34、2012.

6) 西村直也、柳宇、鍵直樹、池田耕一、吉野博、齊藤秀樹、齊藤敬子、鎌倉 良太、小烟美知夫 : 老人福祉施設における室内環境の衛生管理に関する研 究 - 第 2 報-連続測定の結果およびV OC 類の測定結果、空気調和・衛生 工学会論文集、185、pp. 11 18、2012.

7) 乳井厚子、五十嵐由利子、川島美勝、田中正敏、徳田哲男、栃原裕、橋本 修左、梁瀬度子、吉田あきら、牛久保秀忠 : 高齢者居住施設の温熱環境に ついて その 2 冷暖房設備についてのアンケート結果と考察、日本建築 学会大会学術講演梗概集 D 環境工学、pp. 839 840、1994.

8) 牛久保秀忠、五十嵐由利子、川島美勝、田中正敏、徳田哲男、栃原裕、橋 本修左、梁瀬度子、吉田あきら、乳井厚子：高齡者居住施設の温熱環境に ついて - その 3 換気設備・暖冷房コストのついての結果とアンケートの 総括、日本建築学会大会学術講演梗概集 D 環境工学、pp. 841 842、1994.

9) 山岸明浩、五十嵐由利子、飯野由香利 : 新潟県内における高齢者居住住宅 の温熱環境に関する研究 一その 4 冬季における加湿器の運転による湿度 環境の変化、日本建築学会大会学術講演梗概集 D-2、pp. 323 324、2002.
10) 姜燕、龍有二 : 高齢者居住空間の湿度及び乾燥感と加湿器利用状況に関寸 る研究、日本建築学会大会学術講演梗概集 D-2、pp. 275 276、2012.

11）五十嵐由利子、高橋啓子、中嶋亜紀佳、高本麻美 : 特別養護老人ホームに おける冬季の湿度環境改善に関する研究 その 1 加湿設備のある施設に おける実測調查、日本建築学会北陸支部研究報告集 41、pp. 179 182、1998.

12）王春旭、龍有二、姜燕：高齢者福祉施設の湿度環境に関する調查研究 湿 度環境及び加湿器利用状況、日本建築学会研究報告、九州支部 50、pp. 473 476、2011.

13）大㴊律子、橋本修左：高齢者の夏季空調への温冷感に関する調査. 日健医 誌、11 (1)、pp. 40 46、2002.

14）大澤元毅、金勲、阪東美智子：高齢者施設における室内環境と健康背に関 する調查 (第 1 報)、(第 2 報)。平成 26 年度空気調和・衛生工学会大会学 術講演論文集、pp.129-132、pp.133 136、2014.

15）金勲、林基哉、開原典子、大澤元毅、阪東美智子：高齢者施設における冬 期の温度、湿度、CO2 濃度の実測調查及び湿度管理に関する分析、室内環 境、Vol.18 (2)、pp. 77 87、2015.

16）阪東美智子、金勲、大澤元毅 : 特別養護老人ホームにおける環境衛生管理 の現状と課題、保健医療科学、63(4)、pp. 359 367、2014.

17) WELNESS. 2 次医療圈データベースシステム 全国特別養護老人ホーム一 覽データVer2.0.0.x1s、

http://www.wellness.co.jp/siteoperation/msd/index.php?mode=download_do\& file $=$ data_t (accessed 2013-11-08)

18）エネルギーの使用の合理化に関する建築主等及び特定建築物の所有者の 判断の基準 (平成 25 年経済産業省・国土交通省告示第 1 号)、 http://www.mlit.go.jp/common/001016464.pdf (accessed 2014.07.10)

19）厚生労働省 HP、補論 2 ユニットケアについて、 http://www.mhlw.go.jp/topics/kaigo/kentou/15kourei/3b.html (accessed 2017-01-16) 


\title{
MANAGEMENT SITUATION OF INDOOR ENVIRONMENT \\ AND HVAC SYSTEM IN FACILITIES FOR THE ELDERLY
}

\author{
Hoon KIM*, Michiko BANDO**, Haruki OSAWA* \\ and Motoya HAYASHI*** \\ * Senior Researcher, National Institute of Public Health, Dr. Eng. \\ ** Chief Senior Researcher, National Institute of Public Health, Dr. Eng. \\ *** Research Managing Director, National Institute of Public Health, Dr. Eng.
}

Japan has been well on the way to an aging society and entered a super-aged society at 21.5 percent aging rate in 2007, and the facility demand for the elderly is increasing rapidly. More careful control of indoor environment is needed for the elderly, since the autonomous control ability, recuperative and immunological power of them are poorer than healthy people. It is critical to understand the facility managing system and the actual condition of indoor environment in order to improve quality of life such as health and comfort and to prevent infectious diseases in care welfare facilities for the elderly.

Although the related facilities are in high demand, the actual situation of indoor environment has not been clear because there has not been a regulation and control law at all. Cross-sectional study utilizing the questionnaire survey on special nursing homes all over the country was conducted to clarify the management, maintenance and actual condition of indoor environment and building equipment in 2013.

Survey results found that average floor area is $3000 \mathrm{~m}^{2}$ or more, mean building age is 18 years and facilities of more than $30 \%$ have experienced extension and renovation work. While the facilities of conventional type (with multiple bed room) account for more than $60 \%$, unit care type has been popular in facilities built after the 2000 s and the hybrid type combined with conventional and unit care type is not also negligible due to consistent high demand for multiple bed room.

As might be expected, area (climate) and facility age make a difference to HVAC equipment and this study also confirmed it. As the unit care type increases associating with government guidance, the installation of individual air conditioning equipment also expanded countrywide due to the benefits of initial and operating costs, energy conservation and high control performance. While about $60 \%$ of facilities have criteria for the air temperature, criteria for humidity and ventilation are in lower proportion. It is certain that facilities are much more taking care of infectious diseases and dryness since humidity and ventilation criteria are in higher ratio in winter season than in the others. Although they have obviously interests in air quality, hygrothermal environment and energy conservation, their recognition of countermeasure and execution seems not to be sufficient. In addition, there was a problem in knowledge and recognition of facility managers for air conditioning equipment, for example since a large difference was observed in the response rate concerning a central type of ventilation and a central HVAC system. In order to secure and maintain the favorable indoor environment and hygiene in the elderly facilities, it seems appropriate to remark that a professional administrator should be employed as a facility manager, and they should be educated and provided with the related knowledge and techniques. 